\title{
Ressentiment as Suffering: On Transitional Justice and the Impossibility of Forgiveness
}

\author{
Panu Minkkinen*
}

\begin{abstract}
This essay examines the politics of transitional justice through the notion of forgiveness. Conventional notions of forgiveness and justice, as they have been adopted for and utilized in the numerous truth commissions around the world as well as in the theories supporting the work of the commissions, corrupt the transitional process into what Derrida aptly calls the conditional forgiveness of "social therapy." One major shortcoming in these theories has been their inability to adequately deal with the issue of resentment, i.e., the victim who refuses to forgive. Through a closer investigation into the phenomenology of ressentiment (Nietzsche, Max Scheler, Jean Améry), the essay proposes to interpret resentment as a continuation of the suffering that the victim has originally endured. Juridified and subjected to the therapeutic rationalizations of truth commissions, resentment coagulates into a suffering with a utilitarian value. Finally, this essay discusses the possible ways in which a theory of transitional justice could appropriately address the victim's resentment thus rendering his suffering "just" and making unconditional forgiveness possible.
\end{abstract}

Keywords: transitional justice, forgiveness, resentment, Jacques Derrida, Jean Améry

Le moi est haïssable. ${ }^{1}$

—Blaise Pascal

\section{THE UNFORGIVEN}

In his short commentary on pardon in The Science of Right, Immanuel Kant assigns to it a very limited domain within his presentation of law. For Kant, this is quite an understandable position. Pardon represents the "greatest wrong"

Law \& Literature, Vol. I9, Issue 3, pp. 513-53I. ISSN 1535-685X, electronic ISSN I 54I-260I. (C) 2007 by The Cardozo School of Law of Yeshiva University. All rights reserved. Please direct all requests for permission to photocopy or reproduce article content through the University of California Press's Rights and Permissions website, at http:/ / www.ucpressjournals.com/reprintinfo.asp. DOI: IO.I525/lal.2007.19.3.513 
because it detaches the necessary formal link between crime and punishment. But even in its limited use in crimes of treason that directly "victimize" the sovereign, pardon is a right that reveals the sovereign in the "brilliance of his supremacy [Glanz seiner Hoheit]," and this is why it is, as Kant concludes, the only right that is "worth the name "a right of majesty." 2 Pardoning is an immediate and singular majestic intervention by the sovereign, and so it falls outside of the normal scope of what Kant understands as law. But even if it is associated with the "inscrutable" sovereign, pardon remains a right because it interferes with the normal workings of the law. I can "forgive" my debtors because no public law requires me to collect my dues, but a transgression against the law cannot be forgiven, only pardoned.

Nevertheless, this thoroughly juridified notion of pardon can only find meaning on the fringes of law as a tangent in relation to forgiveness, and this is why pardon presents a problem for the systematized account of legal concepts that Kant is so obsessed with. For as soon as the legal concept of pardon touches upon forgiveness, it must by necessity also compromise its conceptual purity. One could, then, claim that Kant's treatment of pardon is short, not because it is unimportant, but because with brevity Kant wishes to avoid the entanglements that would arise if he associated the legal concept too closely with forgiveness. Even language betrays him. The German word for pardon, Begnadigung, implies a "gift of grace," a gratia that, as Augustine would say, is not granted for merits but is, by definition, given free (gratis). ${ }^{3}$ So while the sovereign grants pardon "at his pleasure," forgiveness expects nothing in return. Because it is endowed unilaterally with no requirement for reciprocity, forgiveness presents a threat to the working of the law. Vladimir Jankélévitch describes this threat thus:

The law [droit] continuously codifies and encompasses the gracious movement of forgiveness, and forgiveness continuously escapes beyond the limits within which a massive codex claims to contain it. Refusing to be merely a postscript to written law or a case law of justice, forgiveness is for law [loi] a principle of mobility and fluidity: through the grace of forgiveness, this law remains pneumatic, evasive and approximate. ${ }^{4}$

Even so, law ceaselessly approaches forgiveness in its attempts to rectify its own formal barrenness. The creation and existence of some thirty truth commissions during the last four decades in countries of Central and South 
America, Asia, Africa, and Europe focusing on the possibilities of redress, reconciliation, and transitional justice after periods of intense internal conflict and crimes of the direst kind bear witness to this. If forgiveness corrupts the conceptual and formal purity of law, in truth commissions it is "pure" forgiveness that is corrupted when it takes on pseudo-legal forms. The oft-cited aporia "forgiveness only forgives the unforgivable" that Jacques Derrida adopts from Jankélévitch contrasts a conditional forgiveness requiring an economy of atonement with an unconditional and "pure" one, a "gracious, infinite and non-calculative forgiveness that is granted to the guilty as guilty, even to those who do not repent or ask for it." ${ }^{5}$ Even if forgiveness must always go beyond a mere "therapy of reconciliation," Derrida insists that the opposing poles of the conditional and unconditional must by necessity remain coupled:

The unconditional and the conditional are, no doubt, absolutely heterogeneous, forever, two sides of a limit, but they are also indissociable. In the movement or motion of unconditional forgiveness there is an internal necessity to become effective, manifest, determined, and by determining itself to fold towards the conditional. ${ }^{6}$

But Derrida also leaves this necessity dependent on a will:

if one wants [si l'on veut], and one should do so, forgiveness to be effective, concrete, historical, if one wants it to arrive, to take place by changing things, its purity has to engage itself in a series of all kinds (psycho-sociological, political, etc.). It is between these two poles [PM: of the unconditional and the conditional], irreconcilable but indissociable, that decisions and responsibilities are to be taken.?

"True" forgiveness that can only forgive the unforgivable must then engage with practices that permit forgiveness to take place historically "if one wants," and "one should want to do so." Whose will are we talking about? As far as the atrocities committed are concerned, only the victim can truly forgive. Just as in the case of the right of pardon in law, in truth commissions, forgiveness remains the victim's sovereign and unconditional intervention that cannot be harnessed with structural or political preconditions. We must then also presume that it is also only the victim that can initiate-himself or through his representatives - any conditional requirements of forgiving, any legal or political framework within which unconditional forgiveness will 
eventually acquire its conditional framework and its concrete and historical relevance.

But what about the unwilling? How do we understand a victim who, without seeking reparation or apology, is not prepared to either forgive or to even engage in any process recognizing the possibility or necessity of forgiveness? One of the definitions of "forgive" given by the Oxford English Dictionary is "to give up resentment against an offender." So following Derrida, how can we reconcile — and yet dissociate—-forgiveness and persistent resentment? How can we overcome a resentment that denies any possibility of an unconditional forgiveness and, subsequently, any hope of reconciliation between the victim and his persecutor??

\section{RESSENTIMENT AND MEMORY}

In The Genealogy of Morals, Nietzsche claims that grace (Gnade) is the exclusive privilege of the most powerful and the self-negation of a justice that "does away with itself " by detaching the crime committed from the prescribed punishment. Grace is evidence of how the most powerful can move "beyond the law." ${ }^{10}$ But although Nietzsche seems to associate grace with a superior notion of law, the position of the powerful and the privileges that it entails are also characterized as an original position of man from which the genealogical enquiry into morality commences:

The knightly-aristocratic judgments of value have as their basic assumption a powerful physicality, a blooming, rich, even overflowing health, together with what is required to maintain these qualities—war, adventure, hunting, dancing, war games, and everything that involves strong, free, happy action. ${ }^{11}$

The ability to be gracious is dependent on a creative and active power that contributes towards the ability to forget:

To be unable to take your enemies, your misfortunes, even your bad deeds seriously for very long - that is the sign of a strong and comprehensive nature in which there is a surplus of plastic, creative and curative power that also makes one forget.... ${ }^{12}$

The warrior caste that Nietzsche so admires expresses its creative power either by swiftly putting into effect the retaliation that a suffered injury has 
possibly called for or through the forgiveness of grace, and both actions contribute towards forgetting. The original position of the warrior is, however, subsided with the ascent of the priest caste and Christianity that reinterpret the active and affirmative "noble morality" of the powerful as an evil while simultaneously glorifying suffering, poverty, and powerlessness as morally worthy attributes. And herein also resides the origin of ressentiment:

The slave revolt in morality begins when ressentiment itself becomes creative and gives birth to values: the ressentiment of beings who are prevented from a genuinely active reaction and who compensate for that with a merely imaginary vengeance. $^{13}$

Ressentiment requires, then, two things. Men are never equal in their ability to produces effects in the world. The weak and feeble, whatever the source of that weakness may be, lack the ability to purge themselves by either retaliating or forgiving the injuries afflicted by their persecutors. Instead, the slave bears a grudge and holds on to his resentful feelings. In other words, ressentiment is a will to power that cannot be acted upon. But the slave also attaches positive moral values to the powerlessness that prevents him from acting by settling for an imaginary surrogate in exchange for a promise of a life after. The slave's imaginary revenge, never put into effect but sustained in his memory, is a reactive gesture founded on a negative validation of the other and of the outside world. "I am not you," the man of ressentiment keeps repeating never being able to affirm what he truly is.

Eventually ressentiment finds expression in self-righteous Christian values:

powerlessness which does not retaliate is being falsified into "goodness," anxious baseness into "humility," submission before those one hates to "obedience" (of course, obedience to the one who, they say, commands this submission - they call him God). The inoffensiveness of the weakling, even the cowardice in which he is rich, his standing at the door, his inevitable need to wait around, here these acquire good names like "patience" and are called virtue. That inability-to-take-revenge is called the lack-of-will-for-revenge, perhaps even forgiveness ("for they know not what they do_-only we know what they do!"). And people are also talking about "love for one's enemy" —and sweating as they say it. ${ }^{14}$

For Nietzsche, the magnanimous gesture of forgiveness is curiously akin to justice. True justice arises from the noble morality of the powerful and not 
from revenge and resentment as others have claimed. But Nietzsche's justice, as rarely as it may factually occur, is affirmative and positive. It neither "takes place" nor exists "as such" but is posited in an act of judgment, a corollary of the creative and curative power that forgives:

If the just man truly remains just even towards someone who has injured him (and not just cold, moderate, strange, indifferent: being just is always a positive attitude), if under the sudden attack of personal injury, ridicule, and suspicion, the gaze of the lofty, clear, deep, and benevolent objectivity of the just and judging eye does not grow dark, well, that is a piece of perfection and the highest mastery on earth — even something that it would be wise for people not to expect and certainly not to believe in too easily. ${ }^{15}$

According to Gilles Deleuze, Nietzsche does not mean that ressentiment would be merely reactive. It is a set of reactive forces that ultimately triumph over noble active forces for the very reason that they do not "re-act" to them but become "sensed" (sentz). ${ }^{16}$ If, for Nietzsche, noble morality expresses itself through the ability to forget, Deleuze's man of ressentiment is tormented by his memory. The mnemonic traces of his injury arise from his unconscious and produce a conscious "excitation," a pain that the man of ressentiment confuses locally with his memory. But at the same time, he ceases to act on them. The man of ressentiment is, in other words, unable to forget actively. ${ }^{17}$

Ressentiment is, then, not merely a desire for revenge; it is a set of reactive forces that can no longer be acted upon. And it is by evading the action of active forces that gives revenge the "resentful" means of reversing the relation between active and reactive forces and thus constitutes the slave's triumphant revolt:

Ressentiment is the triumph of the weak as weak, the revolt of the slaves and their victory as slaves. In their victory, the slaves form a type... The type of slave (reactive type) is defined by prodigious memory, by the power of ressentiment. ... ${ }^{18}$

Even if ressentiment is passive in so far as it is a reaction that is not acted upon, the man of ressentiment nevertheless expects to benefit or to gain from everything that he either cannot or will not do. As soon as his expectations of gain are not met, he is able to denounce the external world in an attempt to validate himself as morally worthy: "You are evil, therefore I am good." By doing so, 
the man of ressentiment equates the force that has violated him with a force that he has allegedly refrained from. Deleuze calls this the fiction of a force separated from what it can do:

It is thanks to this fiction that reactive forces triumph. It is, in fact, not sufficient for them to refrain from activity. They must also reverse the relation of forces, they must oppose themselves to active forces and represent themselves as superior. The process of accusation in ressentiment fulfils this task: reactive forces "project" an abstract and neutralized image of force. Such a force detached from its effects will be guilty if it acts, worthy, on the contrary, if it does not. . . .19

But reaction always turns back on itself, and ressentiment is eventually internalized as bad conscience, as a conscience that produces pain by internalizing force:

ressentiment is only appeased once its contagion is spread. Its aim is for all life to become reactive, for those in good health to become sick. It is not enough for it to accuse, the accused must feel guilty. And it is in bad conscience that ressentiment comes into its own and reaches the summit of its contagious power: it changes direction. It's my fault, it's my fault, until the whole world takes up this dreary refrain, until everything active in life develops this same feeling of guilt. $^{20}$

For Nietzsche (and for Deleuze), the resentful victim would then be someone who, due to an innate weakness, is unable to act upon the injuries he has suffered. At the outset, he seems to have three options for action. He can retaliate, which would imply a swift and active reply more or less immediately after the injury has occurred, or he can magnanimously forgive. Or, finally, he can simply actively disregard his persecutor. All options imply a purging or cathartic effect, i.e., a curative power that is characteristic of the noble. The man of ressentiment, on the other hand, holds on to his initial suffering through memory because no cathartic healing is either sought or achieved. Ressentiment is, then, a temporal prolongation of the victim's suffering that both arises from a particular morality and further contributes to it. This morality is merely reactive, never affirmative. It can only validate itself as the lack of something else, as the absence of an "evil" will to power. It detaches power from the results it produces and justifies its aversion to the former through a devaluation of the latter. 


\section{RESSENTIMENT AND REPRESSION}

From Nietzsche's resentful "slave" morality and the "noble" morality of the will to power, Max Scheler develops a more detailed phenomenology of ressentiment as a corrupt bourgeois ethos. ${ }^{21}$ Scheler disagrees about the origins of ressentiment and claims that true Christian love is a "blissful stooping" that requires an abundance of power and nobility. The very idea of Christian love is, however, easily usurped by ressentiment by simulating emotions that correspond to the idea of love. For Scheler, the origin of ressentiment lies in the bourgeois forms of Christian love that he calls "altruism" and "humanitarian love":

It [PM: modern humanitarian love] is not the personal act of love from man to man but, rather, primarily the postulation and evaluation of an impersonal "institution," an institution of welfare. The Samaritan act does not arise from the exuberance of life that bestows blissfully from its abundance and plenitude, lovingly from its inner preparedness and security. It arises from a contagious involvement with a feeling of depression that is manifest in apparent external expressions of anguish and dearth, from a specifically modern "sham pity" and "sympathy." 22

Scheler depicts ressentiment as a lasting mental attitude that arises from the systematic repression of negative emotions and sentiments such as revenge, hatred and malice that, as such, would otherwise be normal aspects of human life. But the repression of these sentiments will eventually lead to a constant tendency to indulge in value delusions and corresponding illusory judgments. The desire for revenge, i.e., a reactive impulse following an injury or an attack, is the most important source of ressentiment. The desire for revenge differs from an act of reprisal because the immediate reactive impulse is postponed to a future time that is deemed to be more appropriate. Postponing the impulse suggests a pronounced sense of powerlessness and a corresponding self-valuation that assigns the deferral of the retaliatory reaction to a weakness or a character flaw in oneself. In addition to the postponement of the reaction, the desire for revenge also includes a conscious conviction that a suffered injury requires an equivalent talionic return given measure for measure. ${ }^{23}$

So in order for the desire for revenge to developinto a more permanent ressentiment, a particular qualification is needed: 
Revenge, envy, the impulse to detract, spite, Schadenfreude, and malice lead to ressentiment only if there occurs neither a moral self-conquest (such as, e.g., genuine forgiveness in the case of revenge) nor an act of some other adequate expression of emotion, e.g., verbal abuse, shaking one's fist, etc., and if this restraint is caused by a pronounced awareness of impotence. . . . It [PM: ressentiment can arise only on the condition that these sentiments are particularly powerful and are coupled with a feeling of impotence and one must, accordingly, "suppress" the acts - either because of physical or psychological weakness, because of fear or anxiety. ${ }^{24}$

Scheler notes that two particularities should be observed in the repression (Verdrängung) of negative emotions. First, the man of ressentiment does not repress the expression of his negative sentiments. The repression of an expression would require conscious moral action that the man of ressentiment is by definition incapable of. In order to come to terms with his inability, he must repress his whole negative impulse, thus detaching his sentiment from any particular individual or incident that may originally have prompted it. Having done so, the man of ressentiment generalizes his negative sentiment so that it can embrace any qualities that were, perhaps, originally associated with a singular individual or incident - i.e., the source of his injury — but that he now identifies everywhere. Second, repression also has an effect on the sentiment that the man of ressentiment is unable to externalize as action. Because the negative sentiment can find no clear external object, the man of ressentiment internalizes it transforming it into self-hatred. ${ }^{25}$

But there is a further social factor that contributes to the development of ressentiment. Scheler claims that the Western ethos of equality that does not recognize differences in power falsely asserts that individuals have a "right" to be comparable with others even if this is factually impossible. Such a "right" creates false expectations, impossible moral demands in so far as they can never be fulfilled. ${ }^{26}$ Moreover, the more the injury suffered mutates into a sense of permanency — even a fatality - the less likely any practical transformation of the situation becomes. Eventually this leads to what Scheler describes as "aimless criticism," an "aversion from power" that does not even expect its demands to be fulfilled but, rather, uses the evil it criticizes as a pretext for its own continued existence. ${ }^{27}$

Ressentiment is sustained through permanent comparison. The "common man”-Scheler's counterpart for Nietzsche's slave—can only recognize 
relative values, i.e., values that exist only in relation to other values. Unlike the noble and the powerful, the man of ressentiment validates himself and his predicament only as measurable comparisons in relation to others: "more" or "less," "better" or "worse," "bigger" or "smaller." This is the basic attribute of what Scheler describes as a careerist upstart or an arriviste (Streber). But if the mentality of relative values is coupled with a sense of impotence that would prevent the common man from actively pursuing his careerist goals, then the comparative tension demanding relief can only find recourse in a delusion of values. And ressentiment provides this delusion:

The sense of superiority or equality that the "common man" seeks in order to relieve the tension is here achieved by an illusory devaluation of the valuable characteristics of the comparable object or by a specific "blindness" in relation to them; but secondly — and herein lies the main achievement of ressentimentby an illusory falsification of the values themselves that in general confer positive values and worthy attributes to the existence and validity of possible comparable objects. ${ }^{28}$

So how would Scheler understand the resentful victim? Although he disagrees about its genealogical origins, Scheler does, however, restate many of the key characteristics of ressentiment that Nietzsche had already outlined. Ressentiment involves the postponement of an act of retaliation or an inability to forgive, both accompanied by a strong sense of impotence. Accordingly, ressentiment once again involves the prolongation of the victim's suffering. But Scheler is clearly more sensitive to the psycho-social mechanisms involved. The resentful victim does not merely suppress a retaliatory response but, indeed, he represses the source of his negative sentiment into the unconscious and thus transforms his ressentiment into a symptom. Once the unconscious origin and the conscious symptom have been dissociated, the negative sentiment demands a continuous — and futile — search for alternative origins. This explains the "contagious" nature of ressentiment. And further, because the victim's attempts to externalize an unconscious origin are futile, the negative tension must eventually backfire. Scheler, then, sees ressentiment as a form of what one could call "moral neurosis."

But Scheler also seems to find a kinship of sorts between the injured victim's ressentiment and the general expressions of empathy with which society at large addresses his suffering. Scheler's sharp criticism of liberal humanism and its allegedly unfounded ethos of equality suggest a reading that would see 
all conditional elements in the work of truth commissions - the juridification of truth, the pseudo-legal procedure, the managerial ethos of "governance," etc. - as a reflection of the same ressentiment that torments the unforgiving victim. Through its symbolic reconstruction of the historical narrative of the past, a truth commission can merely participate in the victim's ressentiment. Participation reinforces the victim's resentful sentiments because it can only offer imaginary surrogates. This hinders the victim's self-affirmation rather than reinforces it.

\section{RESSENTIMENT AND MORALITY}

For Scheler, then, just as for Nietzsche, the resentful victim of an atrocity would be someone unable to act, someone incapable of externalizing the emotional scars of his injuries through either a gracious act of forgiveness or a psychologically purging retaliation because of an innate weakness. The presumption seems to be that man has a natural tendency to defuse any contradictions or tensions that might endanger the tranquility of his world. ${ }^{29}$ The absence of this tendency is first attributed to a factual weakness that is then reinterpreted as normative values. But both authors go beyond the mere description of how the victim creates and adopts these values and proceed to a validation of the morality of ressentiment itself. And in this validation, the victim, unable to externalize his suffering, must ultimately bear the responsibility for his own inadequacies.

A strikingly different take on ressentiment is offered by Jean Améry. ${ }^{30}$ Born Hans Mayer in Vienna in I9I2 to a Jewish-Christian family, Améry was initially an aspiring albeit unsuccessful author. In 1938 , he fled the Nazis first to France and later to Belgium, where he was arrested for his involvement in the resistance movement in I943. Having spent two years in various concentration camps, he returned to Belgium after the war to write articles for various German-language newspapers. In 1966, he finally entered into the consciousness of the German literary scene with the publication of Jenseits von Schuld und Sühne. ${ }^{31}$ This short book, with its obvious allusion to Nietzsche ("Beyond Guilt and Atonement”), is a collection of five essays, each exploring the highly personalized experience of a Holocaust survivor.

One of the book's essays, aptly titled "Ressentiments," is an introspective analysis of the resentful sentiments that the victim of the Shoah persistently 
feels against both his persecutors and their compatriots more generally. Améry recognizes that what eventually sets him apart from both his fellow victims "now gushing over about reconciliation" and his enemies "converted to tolerance" is his inability and unwillingness to appease his ressentiment towards the German people. This, however, obliges the resentful victim to clarify his feelings to those against whom they are directed. A key to understanding Améry's account of what he calls the "essence of victim-existence" is time:

ressentiment is not only an unnatural but also a logically contradictory condition. It nails every one of us onto the cross of his ruined past. Absurdly it demands that the irreversible be turned around, that the event be undone. Ressentiment blocks the exit into the genuine human dimension, the future. ${ }^{32}$

By refusing to accept the "natural" course of time, ressentiment becomes an anti-humanism. One does not resent only the crimes that were committed or those who committed them. The apparent ease with which both the victim's persecutors and the "lofty ethical flights" of mediating third parties manage to turn to an allegedly common future becomes a major catalyst in Améry's ressentiment:

It is impossible for me to accept a parallelism that would have my path run beside that of the fellows who flogged me with a horsewhip. I do not want to become the accomplice of my torturers, rather I demand that they negate themselves and in the negation coordinate with me. ${ }^{33}$

Améry clearly sees any formalized attempt to uncover the "truth" of the crimes committed as a moral insult. In order to make it possible for an offender to assume responsibility for his actions, a process such as a truth commission will try to objectify history into a verifiable narrative of causes and effects which, Améry claims, contradicts the victim's inalienable right to resent. As W. G. Sebald notes in identifying a literary kinship between Améry and the uncompromising radicalism of Bataille and Cioran:

Améry believes as little in the possibility of revenge as in the idea of atonement, which he describes as dubious from the outset: at the most, he considers it of theological significance and therefore irrelevant to him. The issue, then, is not to resolve but to reveal the conflict. The spur of resentment which 
Améry conveys to us in his polemic demands recognition of the right to resentment, entailing no less than a programmatic attempt to sensitize the consciousness of a people "already rehabilitated by time." ${ }^{34}$

And in this respect, Améry considers his torturers and those who initiate processes like truth commissions as co-conspirators:

When I stand by my ressentiments, when I admit that in thinking our problem through I am "biased" [befangen], I still know that I am the captive [Gefangene] of the moral truth of the conflict.... The atrocity as atrocity has no objective character. Mass murder, torture, injury of every kind are objectively nothing but chains of physical events, describable in the formalized language of the natural sciences. . . . Only I possess and possessed the moral truth of the blows that still today roar in my skull, and I am therefore more entitled to judge, not only more than the perpetrator but also more than society that only thinks of its continued existence. ${ }^{35}$

Therefore, any formalized process of reconciliation that is oriented towards the future is immoral, and forgiving in such circumstances implies a shameful subjection to what Améry calls the "natural time" of healing. Precisely because such a conception of healing with time is "natural," Améry insists that it is not only immoral but radically alien to morality. As a moral being, man has both the right and the privilege to contradict any natural occurrence, and this includes the healing that time allegedly brings about. Healing, then, is not a natural phenomenon into which a given process, a truth commission or other, can escort the victim. It is a radical choice that Améry considers to be both contrary to what he understands as morality and evidence of the victim's subjugation to his persecutors.

But Améry does recognize two functional aspects in his ressentiment. On the one hand, ressentiment represents the victim's subjective efforts to purge himself, to turn back time in order to undo the suffering that he has endured. Resenting is neither retaliating nor forgiving, but for the victim it has a cathartic potential. Améry duly admits that his claim is "absurd," but he insists that it is the victim's right because morality is by necessity dissociated from the dictates of "natural time." But ressentiment also has a more objective and historical task, no less absurd or moral than the victim's demand that the irreversible be reversed: ressentiment invokes the German revolution that never took 
place. Face to face with such moral and yet absurd demands, Améry can see but one solution:

... ressentiment is kept alive in one camp and, aroused by it, self-mistrust in the other. Motivated only by the spurs of our ressentiments — and not in the least by a conciliatoriness [Versöhnlichkeit] that is subjectively almost always dubious and objectively hostile to history - the German people would remain sensitive to the fact that they cannot allow a part of their national history to be neutralized by time but must integrate it... it would no longer repress or hush up the twelve years that for us others really were a thousand but claim them as the world and negation of self that it realized, as its negative possession. ${ }^{36}$

There is, however, no objective truth to claim, no common history to recognize, but only the subjective moral truth of a victim who will persistently refuse to forgive. And with every attempt at a practical social arrangement for reconciliation contradicting the moral right of the victim to resent, the possibilities of transitional justice would seem to be very limited.

\section{RESSENTIMENT AND SUFFERING}

The humanistically inclined legal theorist will duly recognize the victim's right not to forgive and to continue resenting his offender. But committed to the ideals of transitional justice, the recognition of such a right can only take place within an already existing process of reconciliation, i.e., through the conditional necessities of forgiveness, irrespective of whether we are talking about a factually existing procedure or merely an intellectual framework. This double gesture of recognizing the victim's right to resent and concurrently sustaining a process that could never have respected such a contradicting right in the first place can only be performed from a position that identifies the theorist with the victim, by partaking in his suffering through an economy of compassion and extending the duration of the process in the victim's name. Such a compassionate position is by necessity an imposition, an intrusion by a third party that, if we are to believe Derrida, necessarily corrupts the structural preconditions of forgiveness into "social therapy."

Jankélévitchcallssuchhumanisticprocesses "intellection,"wheretheprimary aim is to attain forgiveness by understanding the atrocities committed: 
by instituting an abstract fraternity amongst men, intellection recognizes and respects the relative truth of every being and the equal advancement of all beings. But this type of forgiveness has no second person: it deals with the anonymous universality of "third" persons, but it does not address you. Unlike true forgiveness, it is not engaged in the immediate relationship with its face-to-face counterpart, but is impartial. ... ${ }^{37}$

If forgiveness is to play any part in a theory of transitional justice, the theorist must dissociate himself from the "intellection" of committed crimes and adopt a more integral position. But if theory is never victimized and is, therefore, itself never in a position to forgive anything, how can such an integral position be adopted? How can theory engage with the "face-to-face counterpart" of the atrocity it is trying to address?

Perhaps we should view the resentful victim in symptomatic rather than pathological terms. In that case, ressentiment and the victim's outspoken elaborations of his unwillingness to forgive can be best understood as a reliving of his original victimization. As such, ressentiment is not unlike Freud's account of the repetition compulsion in traumatic neuroses where the neurotic patient continuously re-enacts the painful experience in his attempts to bring the trauma under the mastery of the pleasure principle:

the compulsion to repeat also recalls from the past experiences that include no possibility of pleasure, which could not have provided satisfaction to instinctual impulses even if they had since been repressed... . Neurotics now repeat in the transference all these unwanted situations and painful emotions and revive them with great skill. ${ }^{38}$

Through his ressentiment, the victim perpetuates his suffering in a way that clearly contradicts the pleasure principle. He returns to the trauma of the injuries he has suffered without being able to forget or, indeed, without even wanting to do so. Ressentiment is, then, an expression of the death instinct and, consequently, a symptom of the victim's original trauma. In other words, the victim's unwillingness to forgive is the symptom of his suffering rather than the expression of any innate weakness. When theory confronts a resentful victim, it is addressing suffering, and in the theory of transitional justice, the possibility of forgiveness becomes dependent on how theory confronts the suffering of the victim. 
Following Emmanuel Levinas, ressentiment as suffering can be said to be intrinsically "useless." It includes within itself an apparent contradiction. On the one hand, Levinas seems to be saying, suffering is quantifiable data in the consciousness of the victim, but on the other hand, suffering is also a rejection or a refusal to order this data into a meaningful whole. The sensation of the contradiction itself accounts for the misery of suffering, its woe. And in the case of ressentiment, the refusal is audible in the victim's seemingly "irrational" resentment. 39

The suffering that refuses to take on meaning overwhelms the victim more violently and cruelly than any violation of his personal integrity and in Levinas's terms also renders it "useless": because it refuses to make sense, suffering is essentially "for nothing." But for Levinas, this uselessness also marks the possibility of an ethics. The refusal to take on meaning provides an opening through which "a moan, a cry, a groan, or a sigh passes, the original appeal for aid, for healing help, for help from the other me whose alterity, whose exteriority promises salvation." ${ }^{40}$ And it is only by responding to this original appeal that intrinsically useless suffering can become just within the radical humanism that Levinas calls the interhuman: the other's suffering will finally make sense as my suffering for the suffering of the other. ${ }^{41}$

So how can the resentful victim's suffering become my suffering, the theorist's suffering?

I am the offender; I am the object of the victim's ressentiment regardless of whether I am the actual persecutor or have contributed to his suffering through my clumsy attempts at unsolicited understanding and alleviation. Confronted by an impenetrable suffering and an irreconcilable ressentiment, theory finds itself in a situation where it can neither ask for forgiveness - I am not requested to do so or permitted to absolve myself unilaterally-nor thematize forgiveness into effectual social practices that would by necessity undermine its offences. As offender, the only thing left to do is for theory to accept the irreconcilable and the impasse that follows.

There are two ways to read this impasse. A cynical reading will retract and find solace in the liberalist tradition of law that, whatever its other shortcomings may be, can at least formalize the encounter between victim and factual offender into workable solutions. Where no unconditional forgiveness is available, law will settle for the conditional, for clemency and amnesty. This is why truth commissions are procedurally and administratively so easily juridified. And even if they operate at the fringes of law, there is nothing radically 
new about the way they function. It is still a more or less formalized encounter between an offender and a victim before a seemingly neutral third party that endorses the objectified outcome through its authority.

But I believe that there is a more radical way of understanding the impasse. The resentful victim is my absolutely other. Face to face with an unforgiving other, I take responsibility for a suffering that is both impenetrable and incomprehensible. I acknowledge the necessity to avoid any gesture of comprehension or compassion that would reduce the victim into my likeness within a shared and totalizing humanity. As a theorist, I can address the possibility of unconditional forgiveness only by taking on the responsibility of the persecutor.

My relation to my resentful victim is what Blanchot calls a relation of the third kind. Founded neither on a crude identification that would reduce everything to sameness nor on a desire that aspires to sublate the relation between subject and object into oneness, the Other remains a complete "horizonless" stranger who introduces the interruption that makes ethics possible:

in and through this other relation, the other is for me the very presence of the other in his distant infinity, man as absolutely other and radically strange, he who neither yields to the Same nor is exalted to the unity of the Unique. ${ }^{42}$

Theory addresses unconditional forgiveness by negating itself or, as Améry suggests, by claiming the atrocities committed as its own negative possession. By unconditionally accepting the victim's right to resent and by recognizing his suffering as its own doing, theory can begin to work out the ethical preconditions of a transitional justice that would enable forgiveness to take place. The encounter between theory and its resentful victim is the aporia of forgiveness that Derrida identifies, and it is within this aporia that theory, resented and unforgiven, assumes its responsibility.

* My thanks to Véronique Voruz, Colin Perrin, and Marty Slaughter for their comments.

I. Blaise Pascal, Pensées (Paris: Librairie Général Française, I972), 209.

2. Immanuel Kant, "Die Metaphysik der Sitten," in Immanuel Kant, Gesammelte Schriften, Erste Abtheilung: Werke, Band VI, Herausgegeben von der Königlich Preussischen Akademie der Wissenschaften (Berlin: Georg Reimer, I914), 203-494 at 337.

3. "... non meritis redditur, sed gratis datur, propter quod gratia nominator." Aurelius Augustinus, "De natura et gratia contra Pelagium ad Timasium et Iacobum liber unus," in Aurelius Augustinus, Patrologia cursus completus, series Latina, Tomus XLIV (Petit-Montrouge: J.P. Migne, I845), 247-290 at 249 (IV, 4). 
4. Vladimir Jankélévitch, Le Pardon (Paris: Aubier, 1967), 17.

5. Jacques Derrida, "Le siècle et le pardon. Entretien," Le Monde des Débats, No 9, décembre I999, IO-I7 at I2.

6. Jacques Derrida, Pardonner: l'impardonnable et l'imprescriptible (Paris: L'Herne, 2005), 76.

7. See Derrida, supra note 5 at 15.

8. The etymology of the English verb "forgive" is similar to that of its German equivalent vergeben, literally "to give away," whereas the Latin perdonare implies "giving completely."

9. See also Thomas Brudholm and Thomas Cushman, "Special Issue: The Importance of Negative Emotions in Post-Conflict Societies," 5 Journal of Human Rights I (2006), 5-6.

Iо. Friedrich Nietzsche, "Zur Genealogie der Moral. Ein Streitschrift," in Friedrich Nietzsche, Werke. Kritische Gesamtausgabe, Sechste Abteilung. Band II, Herausgegeben von Giorgio Colli und Mazzino Montinari (Berlin: de Gruyter, I968), 257-430 at 324-325 (Part II, \ Io).

II. $I d$. at 280 (Part I, \7).

I2. Id. at 287 (Part I, $\left.\int \mathrm{IO}\right)$.

I3. Id. at 284 (Part I, $\left.\int \mathrm{IO}\right)$.

I4. Id. at 295-296 (Part I, \I4).

I5. Id. at 326-327 (Part II, $\int_{\text {II }}$ ). On Nietzsche's particular take on "positive law," see Philippe Nonet, "What Is Positive Law," Ioo The Yale Law Journal 667 (1990).

I6. Gilles Deleuze, Nietzsche et la philosophie (Paris: PUF, I962), I27-I28.

I7. Id. at $13 \mathrm{I}-\mathrm{I} 32$.

I8. Id. at $\mathrm{I} 34$.

I9. Id. at I40-I4I.

20. Id. at I 5 I.

2I. Scheler's essay has been published in English as Max Scheler, Ressentiment, William W. Holdheim, trans. (New York: Free Press, 1961).

22. Max Scheler, "Das Ressentiment im Aufbau der Moralen," in Max Scheler, Gesammelte Werke, Band 3. Vom Umsturz der Werte. Abhandlungen und Aufsätze, Vierte durchgesehene Auflage. Herausgegeben von Maria Scheler (Berlin: Francke, I955), 33-I47 at IOI-IO2.

23. Id. at 38-4I.

24. Id. at $4 \mathrm{I}$.

25. Id. at 59-63.

26. One can, perhaps, see here a certain relationship between Scheler and "anomic" accounts of social alienation and exclusion.

27. See Scheler, supra note 22 at $43-44$.

28. Id. at 49-50.

29. This is clearly akin to Freud's notion of the Nirvana-principle. See Sigmund Freud, "Jenseits des Lustprinzips," in Sigmund Freud, Gesammelte Werke, Dreizehnter Band (Frankfurt am Main: Fischer, 1999), I-69 at 59-60.

30. I am grateful to Thomas Brudholm for bringing my attention to Améry's work and its relevance for the theories that underpin the work of truth commissions. See Thomas Brudholm, Resentment's Virtue: Jean Améry and the Refusal to Forgive (Philadelphia: Temple University Press, 2008), and Thomas Brudholm, "The Justice of Truth and Reconciliation," I8 Hypatia 2, I89-196 (2003). A recent biography of Améry is Irene Heidelberger-Leonard, Jean Améry — Revolte in der Resignation. Eine Biographie (Stuttgart: KlettCotta, 2004). See also Aleida Assmann, “Two Forms of Resentment: Jean Améry, Martin Walser and German Memorial Culture," 30 New German Critique 3, I23-133 (2003).

3I. Published in English as Jean Améry, At the Mind's Limits: Contemplations by a Survivor on Auschwitz and Its Realities, Sidney Rosenfeld and Stella P. Rosenfeld, trans. (London: Granta Books, I980).

32. Jean Améry, “Jenseits von Schuld und Sühne," in Jean Améry, Werke, Band 2, Heruasgegeben von Irene Heidelberger-Leonard (Stuttgart: Klett-Cotta, 2002), 7-I77 at I28. 
33. Id. at I29.

34. W. G. Sebald, On the Natural History of Destruction, Anthea Bell, trans. (London: Penguin, 2004), I6I-I62.

35. See Améry, supra note 32 at I30-I3I.

36. Id. at $\mathrm{I} 42-\mathrm{I} 43$.

37. See Jankélévitch, supra note 4 at $92-93$.

38. See Freud, supra note 29 at I8-I9.

39. Emmanuel Levinas, "La souffrance inutile," in Emmanuel Levinas, Entre nous: Essais sur le penser-à-l'autre (Paris: Grasset, I99I), I07-II9 at I07-I09. A similar Levinasian theme in relation to Nietzsche is examined in Marinos Diamantides, "In the Company of Priests: Meaninglessness, Suffering and Compassion in the Thoughts of Nietzsche and Levinas," 24 Cardozo Law Review 3, 1275 (2003).

40. See Levinas, supra note 39 at Io9-I Io [PM: footnote omitted].

4I. Id. at III.

42. Maurice Blanchot, "Le rapport du troisième genre. Homme sans horizon," in Maurice Blanchot, L'entretien infini (Paris: Gallimard, 1969), 94-105 at I05. See also Lars Iyer, "The Unbearable Trauma and Witnessing in Blanchot and Levinas," 6 Janus Head: Journal of Interdisciplinary Studies in Literature, Continental Philosophy, Phenomenological Psychology, and the Arts I, 37 (2003) 
